\title{
The impact of serum anti-Müllerian hormone levels on preeclampsia prediction: a case control study
}

\author{
Begüm Aydoğan Mathyk', Berna Aslan Çetin², Sibel Gülova', Nazlı Yenigül', \\ Işıl Ayhan', Ayşe Ender Yumru' \\ ${ }^{1}$ Gynecology and Obstetrics Clinic, Şişli Etfal Hamidiye Training and Research Hospital, Istanbul, Turkey \\ ${ }^{2}$ Gynecology and Obstetrics Clinic, Kanuni Sultan Siileyman Training and Research Hospital, Istanbul, Turkey
}

\begin{abstract}
Objective: The aim of our study is to investigate serum antiMüllerian hormone (AMH) levels in patients who developed preeclampsia at the third trimester.

Methods: Our study was conducted as a prospective case control study. The patients who were diagnosed with preeclampsia over 34 weeks of gestation were included in the study. Healthy pregnant women at the same weeks of gestation were included in the control group. The demographic characteristics, clinical and laboratory parameters, gestational outcomes and serum AMH values of the patients were compared.

Results: A total of 62 pregnant women (32 preeclamptic and 30 control cases) were included in our study. The demographic data were similar in two groups. Systolic blood pressure, diastolic blood pressure, uric acid value and Esbach value were found to be significantly higher in the preeclampsia group. Serum AMH values were $0.79 \pm 0.40 \mathrm{ng} / \mathrm{ml}$ in the preeclampsia group and $1.45 \pm 0.93 \mathrm{ng} / \mathrm{ml}$ in the control group $(\mathrm{p}=0.01)$. There was a negative correlation between serum $\mathrm{AMH}$ values and the systolic blood pressure $(\mathrm{r}=-0.292, \mathrm{p}=0.02)$.

Conclusion: Serum AMH values are lower in the preeclamptic pregnant women at the third trimester compared to normotensive pregnant women.
\end{abstract}

Keywords: Third trimester, AMH, preeclampsia.

\section{Introduction}

Preeclampsia is a gestational complication in a pregnant woman who is healthy previously but develops hypertension and proteinuria after 20 weeks of gesta-

\section{Özet: Serum anti-Müllerian hormon düzeylerinin preeklampsi öngörüsündeki yeri: Olgu kontrol çalışması}

Amaç: Çalışmamızın amacı üçüncü trimesterde preeklampsi gelişen hastalarda serum anti-Müllerian hormon (AMH) değerlerini incelemektir.

Yöntem: Çalışmamız prospektif olgu kontrol çalışması olarak yürütüldü. 34. gebelik haftasının üzerinde preeklampsi tanısı alan hastalar çalışmaya dahil edildi. Kontrol grubu olarak aynı gebelik haftalarındaki sağlıklı gebeler seçildi. Hastaların demografik özellikleri, klinik ve laboratuvar parametreleri, gebelik sonuçları ve serum AMH değerleri karşılaştırıldı.

Bulgular: Çalışmamıza 32 preeklamptik ve 30 kontrol olmak üzere toplam 62 gebe dahil edildi. Demografik veriler iki grup arasında benzer saptandı. Sistolik kan basıncı, diyastolik kan basıncı, ürik asit değeri, Esbach değeri preeklampsi grubunda anlamlı olarak daha yüksek saptandı. Serum AMH değerleri preeklampsi grubunda $0.79 \pm 0.40 \mathrm{ng} / \mathrm{ml}$, kontrol grubunda $1.45 \pm 0.93 \mathrm{ng} / \mathrm{ml}$ olarak saptand $1(\mathrm{p}=0.01)$. Serum AMH değerleri ile sistolik kan basıncı arasında negatif korelasyon saptandi $(\mathrm{r}=-0.292, \mathrm{p}=0.02)$.

Sonuç: Serum AMH değerleri üçüncü trimesterde preeklamptik gebelerde normotansif gebelere göre daha düşüktür.

Anahtar sözcükler: Üçüncü trimester, AMH, preeklampsi. Preeclampsia has two types, which are early-onset and late-onset. ${ }^{[4]}$ Its physiopathology is still unclear. It has been suggested that placental hypoxia and reperfusion

Correspondence: Berna Aslan Çetin, MD. Clinic of Obst. \& Gyn., Kanuni Sultan Süleyman Training and Research Hospital, Istanbul, Turkey. e-mail: bernaaslan14@hotmail.com Received: June 18, 2018; Accepted: August 9, 2018

Please cite this article as: Aydoğan Mathyk B, Aslan Çetin B, Gülova S, Yenigül N, Ayhan I, Ender Yumru A. The impact of serum anti-Müllerian hormone levels on preeclampsia prediction: a case control study. Perinatal Journal 2018;26(2):92-96.

๑)2018 Perinatal Medicine Foundation
Available online at: www.perinataljournal.com/20180262007 doi: $10.2399 /$ prn.18.0262007 QR (Quick Response) Code:

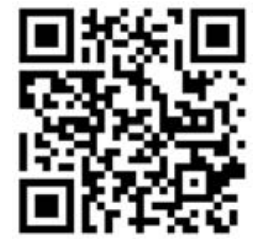


developing as a result of a problem in placental invasion are the reasons of early-onset preeclampsia. ${ }^{[5]} \mathrm{It}$ is considered that late-onset preeclampsia is a maternal endothelial and vascular disease. ${ }^{[6,7]}$ Many molecules have been investigated for the prediction of preeclampsia. ${ }^{[8,9]}$ Anti-Müllerian hormone (AMH) is a glycoprotein hormone from the transforming growth factor family and it is also called Müllerian inhibiting substance (MIS). ${ }^{[10,11]} \mathrm{AMH}$ is a hormone inhibiting the development of Müllerian ducts in male embryo. In women, it is secreted by granulose cells in small antral and preantral follicles of ovary. ${ }^{[12]}$ Serum AMH levels were found lower in women with the history of preeclampsia than normotensive women, and it has been suggested that vascular problems may have an impact on ovarian aging. ${ }^{[13,14]}$ The role of $\mathrm{AMH}$ in the cardiovascular system in addition to the endocrine system has been highlighted in the studies performed in recent years. The aim of our study is to investigate the activity of serum AMH levels in cases with late-onset preeclampsia.

\section{Methods}

After the approval of ethics committee was obtained, our study was conducted as a prospective case control study in the Şişli Hamidiye Etfal Training and Research Hospital of Health Sciences University between January 2015 and January 2016.

The patients who were diagnosed with preeclampsia after 34 weeks of gestation were included in the study. Healthy pregnant women at the same weeks of gestation were included in the control group. The pregnancies below 34 weeks of gestation, the patients with body mass index (BMI) over 35 and the patients whose data could not be accessed completely were excluded from the study.

Preeclampsia is defined as the condition where systolic blood pressure measured twice with 4-hour interval is $>140 \mathrm{mmHg}$ and diastolic blood pressure is $>90 \mathrm{mmHg}$ in pregnant women who were previously normotensive, and protein level in 24 -hour urine is $>300 \mathrm{mg} / \mathrm{dL}$ or protein/creatinine level in spot urine is $>0.3 \mathrm{mg} / \mathrm{dL}$. In the absence of proteinuria, there are also thrombocytopenia (platelet count $<100,000 / \mu \mathrm{L}$ ) accompanying the hypertension, impaired liver function tests (increased serum transaminase level at least two times higher than normal levels), newly-developed renal failure (serum creatinine levels $>1.1 \mathrm{mg} / \mathrm{dL}$ or two times higher than the previous levels), pulmonary edema or new-onset cerebral or visual disorders. ${ }^{[4]}$ The demographic characteristics, clinical and laboratory parameters, gestational outcomes and serum $\mathrm{AMH}$ values of the patients measured at the third trimester were compared. Serum AMH levels of the patients were measured at the time of admission. After the samples were collected in lithium-heparin tubes, serum AMH level was measured by Cobas device (Roche Diagnostics, Risch-Rotkreuz, Switzerland) using Elecsys reagent kit (Elecsys Corporation, Lenexa, KS, USA) by 'ECLIA' method which is electrochemiluminescence immunologic test.

\section{Statistical analysis}

When analyzing the data of the study, SPSS (Statistical Package for Social Sciences; SPSS Inc, Chicago, IL, USA) for Windows 20.0 was used for statistical analysis. Normal distribution was evaluated by KolmogorovSmirnov test. Independent $t$ test was used for parametrically distributed numeric data, and Mann-Whitney U test was used for non-parametrically distributed numeric data. For the categorical data, chi-square test was used for parametric data and Fisher's exact test for non-parametric data. For the correlations between serum AMH levels and other factors, Pearson's or Spearman's correlation analysis was used according to the distribution of data. The results were presented as mean \pm standard deviation. $\mathrm{p}<0.05$ was considered statistically significant.

\section{Results}

A total of 62 pregnant women (32 preeclamptic and 30 control cases) were included in our study. There was no difference between two groups in terms of the demographic data. Systolic blood pressure, diastolic blood pressure, uric acid value and Esbach value were found to be significantly higher in the preeclampsia group. Fetal birth weight and week of gestation at the time of delivery were significantly lower in the preeclampsia group (Table 1).

Serum AMH values were $0.79 \pm 0.40 \mathrm{ng} / \mathrm{ml}$ in the preeclampsia group and $1.45 \pm 0.93 \mathrm{ng} / \mathrm{ml}$ in the control group ( $\mathrm{p}=0.01)$. Serum AMH levels were significantly lower in the preeclampsia group (Table 1).

The correlation between serum AMH values and other factors was analyzed. In the correlation analysis, 
Table 1. Comparison of preeclampsia and control groups.

\begin{tabular}{|c|c|c|c|}
\hline & Preeclampsia $(n=32)$ & Control $(n=30)$ & p-value \\
\hline Age & $28.56 \pm 6.8$ & $26.31 \pm 4.04$ & 0.30 \\
\hline $\mathrm{BMI}\left(\mathrm{kg} / \mathrm{m}^{2}\right)$ & $29.2 \pm 1.80$ & $28.1 \pm 1.59$ & 0.06 \\
\hline Gravida & $2.05 \pm 0.15$ & $2.16 \pm 0.12$ & 0.58 \\
\hline Parity & $0.77 \pm 0.12$ & $0.87 \pm 0.1$ & 0.33 \\
\hline Systolic blood pressure (mmHg) & $153 \pm 11.2$ & $106 \pm 12.2$ & $0.001 *$ \\
\hline Diastolic blood pressure $(\mathrm{mmHg})$ & $95.2 \pm 7.4$ & $70 \pm 8.8$ & 0.001 * \\
\hline AST (U/l) & $24.6 \pm 6.3$ & $24.5 \pm 7.5$ & 0.80 \\
\hline $\operatorname{ALT}(\mathrm{U} / \mathrm{l})$ & $20.7 \pm 4.49$ & $21.1 \pm 4.96$ & 0.73 \\
\hline Uric acid (mg/dl) & $5.2 \pm 0.76$ & $3.06 \pm 0.55$ & $0.001 *$ \\
\hline Week of gestation when AMH level was measured & $35.46 \pm 1.13$ & $35.26 \pm 1.28$ & 0.514 \\
\hline Week of gestation at the time of delivery & $36.24 \pm 3.1$ & $38.5 \pm 1.31$ & $0.02 *$ \\
\hline Birth weight (g) & $3085 \pm 474$ & $3477 \pm 328.4$ & $0.04 *$ \\
\hline Esbach (mg/day) & $725.6 \pm 618.3$ & - & - \\
\hline Serum AMH (ng/ml) & $0.79 \pm 0.40$ & $1.45 \pm 0.93$ & $0.01 *$ \\
\hline
\end{tabular}

AMH: anti-Müllerian hormone; BMI: body mass index. ${ }^{*} p<0.05$ is statistically significant.

negative correlation was found between the systolic blood pressure and serum AMH values $(r=-0.292$, $\mathrm{p}=0.02$ ) (Table 2). No correlation was found between serum AMH levels and age, gravida, BMI, week of gestation and uric acid values (Table 2).

\section{Discussion}

In our study, we found that serum AMH values measured at the third trimester was lower in the preeclamptic pregnant women compared to the healthy pregnant women. Also, we found negative correlation between serum AMH values and systolic blood pressure.

Preeclampsia is a complication seen frequently during the pregnancy and it is still one of the leading reasons in the world for fetal morbidity and mortality. ${ }^{[15]}$ The physiopathology of preeclampsia is still unclear. ${ }^{[16]}$ Some theories claim that genetic predisposition and the imbalance between thromboxane and prostacyclin are effective factors for the development of preeclampsia. This indicates that the maternal immune system has a significant role in the preeclampsia. ${ }^{[15]}$ In the preeclampsia, placental disorders develop between 10 and 20 weeks of gestation, and biochemical and clinical findings can only be revealed weeks, even months after these changes.

$\mathrm{AMH}$ is a glycoprotein hormone from the transforming growth factor family and it is also called
MIS. ${ }^{[10]}$ Being a reliable indicator of ovarian reserve in particular, it is a significant marker used in ovary stimulating treatments, dose selection, prediction of poor response and ovarian hyperstimulation syndrome (OHSS), and diagnosis of polycystic ovary syndrome (PCOS) ${ }^{[17]}$ After the role of AMH in the endocrine system, its levels and physiology during pregnancy have been investigated. Könünger et al. showed that AMH levels decreased during pregnancy and they reported that the reason of this decrease is the suppression of ovary. ${ }^{[16]}$ After delivery, maternal AMH levels recover rapidly.

$\mathrm{AMH}$ levels in pregnant women were first investigated by La Marca et al. In their study, the authors analyzed

Table 2. Correlation analysis according to serum AMH level.

\begin{tabular}{lcc} 
& Correlation coefficient & p-value \\
Age & -0.047 & 0.716 \\
Gravida & -.0197 & 0.126 \\
Parity & -0.186 & 0.148 \\
BMI & -0.150 & 0.245 \\
Week of gestation & 0.154 & 0.233 \\
Systolic blood pressure & -0.292 & $0.021^{*}$ \\
Diastolic blood pressure & -0.248 & 0.052 \\
Uric acid & -0.164 & 0.203 \\
Birth weight & 0.017 & 0.894 \\
1-minute Apgar & 0.100 & 0.440 \\
\hline
\end{tabular}

BMI: body mass index. ${ }^{*} \mathrm{p}<0.05$ is statistically significant. 
AMH levels during pregnancy and in the periods right after the delivery. ${ }^{[18]}$ In this study, it has been showed that there were no significant changes in AMH levels during pregnancy. It was seen that there was a decrease in the AMH levels at the third trimester which was not statistically significant. Although it is controversial if there is any placental $\mathrm{AMH}$ production or not, $\mathrm{AMH}$ levels decrease after the delivery. On the other hand, the impact of high estrogen levels on $\mathrm{AMH}$ gene decreases after the delivery. High level of progesteron during delivery may cause a decrease in follicles. ${ }^{[18]}$ It has been shown in other studies that there is a correlation between AMH and estradiol. AMH affects FSH sensitivity in ovaries and regulates estradiol levels. ${ }^{[19]}$

Preeclampsia is the result of an impaired vascular condition and it has been shown that impaired vascular condition may cause the early aging of ovary. ${ }^{[20]}$ When the serum AMH levels of women with preeclampsia history and normotensive women are compared, it was found lower in women with preeclampsia $(2.00 \pm 1.87$ $\mu \mathrm{g} / \mathrm{L}$ vs. $2.26 \pm 2.56 \mu \mathrm{g} / \mathrm{L}) .{ }^{[20]}$ There are limited numbers of studies in the literature about the serum AMH levels in patients who were diagnosed with preeclampsia during pregnancy. ${ }^{[14,21]}$ Shand et al. found that AMH levels at the first trimester were lower in preeclamptic pregnant women compared to normotensive pregnant women. ${ }^{[2]}$ Tokmak et al. found lower levels of third trimester $\mathrm{AMH}$ levels in preeclamptic pregnant women compared to normotensive pregnant women, but they found no correlation between poor gestational outcomes and AMH levels. ${ }^{[14]}$ In the study, third trimester $\mathrm{AMH}$ value was $0.62 \pm 0.51 \mathrm{ng} / \mathrm{ml}$ in the preeclampsia group while it was $0.93 \pm 0.83 \mathrm{ng} / \mathrm{ml}$ in the control groups. ${ }^{[14]}$ In our study, we found that $\mathrm{AMH}$ levels were lower in the pregnant women diagnosed with preeclampsia at the third trimester compared to the healthy pregnant women $(0.79 \pm 0.40 \mathrm{ng} / \mathrm{ml}$ vs. $1.45 \pm 0.93 \mathrm{ng} / \mathrm{ml})$. Also, we found reverse correlation between serum $\mathrm{AMH}$ values and systolic blood pressure in our study. Our finding supports our hypothesis that the vascular factors in preeclamptic patients may suppress serum AMH level.

We believe that the low AMH levels in preeclamptic pregnant women are the result of the inhibition ovarian AMH production by vascular factors. Showing the correlation between premenopausal cardiovascular risk factors and early menopause ${ }^{[22]}$ and finding lower $\mathrm{AMH}$ levels in women with preeclampsia history ${ }^{[20]}$ support the hypothesis that vascular factors accelerate ovarian aging. When a correlation was found between low serum AMH levels and cardiovascular risk in the recent studies, ${ }^{[2,24]}$ other studies have started to investigate the functions of AMH on systems in addition to reproductive system. Although the receptor of AMH in placenta has been shown regarding to the pregnancy, there is still not sufficient information about the placental production of $\mathrm{AMH}$ in the literature. Also, further studies are needed to investigate the role of serum $\mathrm{AMH}$ levels at the first trimester in the prediction of early-onset preeclampsia and late-onset preeclampsia.

\section{Conclusion}

Consequently, serum AMH values are lower in the preeclamptic pregnant women at the third trimester compared to normotensive pregnant women. There is a negative correlation between serum AMH levels and systolic blood pressure.

Conflicts of Interest: No conflicts declared.

\section{References}

1. Young BC, Levine RJ, Karumanchi SA. Pathogenesis of preeclampsia. Annu Rev Pathol 2010;5:173-92.

2. Duley I. Maternal mortality associated with hypertensive disorders of pregnancy in Africa, Asia, Latin America and the Caribbean. Br J Obstet Gynaecol 1992;99:547-53.

3. The Eclampsia Trial Collaborative Group. Which anticonvulsant for women with eclampsia? Evidence from the Collaborative Eclampsia Trial. Lancet 1995;345:1455- 63.

4. Von Dadelszen P, Magee LA, Roberts JM. Subclassification of preeclampsia. Hypertens Pregnancy 2003;22:143-8.

5. Kimura C, Watanabe K, Iwasaki A, Mori T, Matsushita H, Shinohara K, et al. The severity of hypoxic changes and oxidative DNA damage in the placenta of early-onset preeclamptic women and fetal growth restriction. J Matern Fetal Neonatal Med 2013;26:491-6.

6. Myatt L, Roberts JM. Preeclampsia: syndrome or disease? Curr Hypertens Rep 2015;17:83.

7. Steegers EA, Von Dadelszen P, Duvekot JJ, Pijnenborg R. Preeclampsia. Lancet 2010;376:631-44.

8. Meloni P, D’Angeli I, Piazze J, Cerekya A, Simari T, Pala A, et al. First trimester PAPP-A levels associated with early prediction of pregnancy induced hypertension. Hypertens Pregnancy 2009;28:361-8.

9. Huang T, Hoffman B, Meschino W, Kingdom J, Okun N. Prediction of adverse pregnancy outcomes by combinations of first and second trimester biochemistry markers used in the routine prenatal screening of Down syndrome. Prenat Diagn 2010;30:471-7. 
10. La Marca A, Sighinolfi G, Radi D, Argento C, Baraldi E, Artenisio AC, et al. Anti-Mullerian hormone (AMH) as a predictive marker in assisted reproductive technology (ART). Hum Reprod Update 2010;16:113-30.

11. Nardo LG, Gelbaya TA, Wilkinson H, Roberts SA, Yates A, Pemberton P, et al. Circulating basal anti-Müllerian hormone levels as predictor of ovarian response in women undergoing ovarian stimulation for in vitro fertilization. Fertil Steril 2009;92:1586-93.

12. Fanchin R, Schonäuer LM, Righini C, Guibourdenche J, Frydman R, Taieb J. Serum anti-Müllerian hormone is more strongly related to ovarian follicular status than serum inhibin B, estradiol, FSH and LH on day 3. Hum Reprod 2003;18: $323-7$.

13. Köninger A, Schmidt B, Mach P, Damaske D, Nießen S, Kimmig R, et al. Anti-Mullerian-hormone during pregnancy and peripartum using the new Beckman Coulter AMH Gen II Assay. Reprod Biol Endocrinol 2015;13:86.

14. Tokmak A, Güney G, Aksoy RT, Guzel AI, Topcu HO, Keçecioğlu TS, et al. May maternal anti-mullerian hormone levels predict adverse maternal and perinatal outcomes in preeclampsia? J Matern Fetal Neonatal Med 2015;28:1451-6.

15. Papageorgiou AT, Yu CHK, Bindra R, Pandis G, Nicolaides KH; Fetal Medicine Foundation Second Trimester Screening Group. Multicenter screening for pre-eclampsia and fetal growth restriction by transvaginal uterine artery Doppler at 23 weeks of gestation. Ultrasound Obsest Gynecol 2001;18:4419.

16. Bronses IA. Morphological changes in utero-placental bed, in pregnancy hypertension. Clin Obstet Gynaecol 1977;4:57393.

17. La Marca A, Giulini S, Tirelli A, Bertucci E, Marsella T, Xella $S$, et al. Anti-Müllerian hormone measurement on any day of the menstrual cycle strongly predicts ovarian response in assisted reproductive technology. Hum Reprod 2007;22:76671.

18. La Marca A, Giulini R, Orvieto R, Volpe A. Anti -Müllerian hormone concentrations in maternal serum during pregnancy. Hum Reprod 2005;20:1569-72.

19. Kevenaar ME, Themmen AP, Laven JS, Sonntag B, Fong SL, Uitterlinden AG, et al. Anti-Müllerian hormone and antiMüllerian hormone type II receptor polymorphisms are associated with follicular phase estradiol levels in normo-ovulatory women. Hum Reprod 2007;22:1547-54.

20. Yarde F, Maas AH, Franx A, Eijkemans MJ, Drost JT, van Rijn BB, et al. Serum AMH levels in women with a history of preeclampsia suggest a role for vascular factors in ovarian aging. J Clin Endocrinol Metab 2014;99:579-86.

21. Shand AW, Whitton K, Pasfield A, Nassar N, McShane M, Han X, et al. Evaluation of anti-Mullerian hormone in the first trimester as a predictor for hypertensive disorders of pregnancy and other adverse pregnancy outcomes. Aust N Z J Obstet Gynaecol 2014;54:244-9.

22. Kok HS, van Asselt KM, van der Schouw YT, van der Tweel I, Peeters PH, Wilson PW, et al. Heart disease risk determines menopausal age rather than the reverse. J Am Coll Cardiol 2006;47:1976-83.

23. de Kat AC, Verschuren WM, Eijkemans MJ, Broekmans FJ, van der Schouw YT. Anti-Müllerian hormone trajectories are associated with cardiovascular disease in women: results from the Doetinchem cohort study. Circulation 2017;135:556-65.

24. de Kat AC, Verschuren WM, Eijkemans MJ, van der Schouw YT, Broekmans FJ. The association of low ovarian reserve with cardiovascular disease risk: a cross-sectional populationbased study. Hum Reprod 2016;31:1866-74. 